Polloy, Planning, and Researoh

WORKING PAPERS

World Devologment Report

Office of the Vicu President

Development Economics

The World Barik

July 1988

WPS 37

\title{
Black Market Premia, Exchange Rate Unification, and Inflation in Sub-Saharan Africa
}

\author{
Brian Pinto
}

The black market premium on foreign exchange is an implicit tax on exporters -- and should be shrunk in many cases. But the gap between the official and black market exchange rates without raising taxes or cutting government spending could raise inflation substantially. 


\section{WORKING PAPERS}

World Development Report

In countries where the black market premium on foreign exchange is exceptionally high, often more than 100 percent, lowering the black market rate to a level close to the marketdetermined official rate will improve the balance of payments and increase exports. Floating the currency to depreciate the real exchange rate and make exports more competitive can raise inflation substanti_lly, however, as govemments replace the lost revenue from exports. Inflation will occur even if real government spending remains constant unless there are new taxes or spending cuts to compensate for the loss of implicit export tax revenues.

To avoid costly surges in inflation, exchange rate reform may have to proceed slowly, otherwise the depreciation is likely to mect with considerable political and social opposition as inflation rises.

Some additional guidelincs can ease the problems in countries moving from a fixed to a floating exchange rate:

- Legitimizing the black market so that it can take over commercial transactions could be an iinportant step in the liberalizing process.

- Policymakers should weigh the decision to introduce foreign currency-denominated ac- counts carefully because creating such accounts can raise the rate of inflation.

- If governments adopt a system with a fixed and a floating rate, the floating rate should apply to all commercial transactions and the fixed rate to purcly government transactions and interest payments on existing but not new debt.

- Covernments tackling the black market problem can speed up information to the banking network. Information on credit, trade, and prices is essential to market participants and ellhances the gor mment's credibility - an essential factor in the reform process.

Once the government closes the spread between the official and black market rates, it faces a decision on whether to continue with a float permanently. evidence from developing countries over the next few years should give some insights into this issue.

This paper is a background paper for the 1988 World Development Report. Copies are available free from the World Bank, $1818 \mathrm{H}$ Strect NW, Washington, DC 20433. Please contact Rhoda Blade-Charest, room S13-060, extension 33754.

The PPR Working Paper Series disseminates the findings of work under way in the Bank's Policy, Planning, and Research Complex. An objective of the series is to get these findings out quickly, cven if presentations are less than fully polished. The findings, interpretations, and conclusions in these papers do not necessarily represent official policy of the Bank. 


\title{
Black Market Premia, Exchange Rate Unification, and Inflation in Sub-Saharan Africa
}

\author{
Brian Pinto
}

Table of Contents

\section{Page}

I. Exchange Rate Unification...................................................................................

II. Real Exchange Rates, Inflation and the Black Market Premium......................

Real Exchange Rate........................................................................................ 6

Inflation Tax and Export Tax..................................................................... 7

Trade-off Between Inflation and Premium................................................. 9

III. Country Experiences with Unification.................................................................... 15

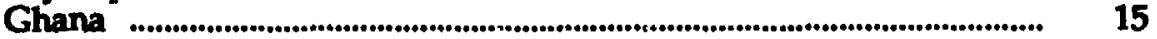

Assessment of the Ghanian Response.............................................

Zaire

Initial Conditions............................................................................. 24

Transition to United Float.............................................................. 24

Sierra Leone....................................................................................................... 27

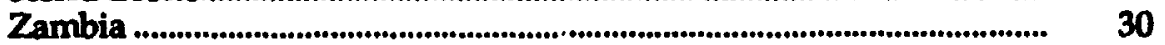

Assessment of the Zambian Experience...................................... 32

IV. Concluding Remarks....................................................................................... 35

Policy Conditionality: The Budget and Exchange Rate Arrangements 35

Summing Up: Some Guidelines for the Transition................................... 36

40

Appendix: Proof that the Production Possibility Frontier (PPF) is Concave..... $\quad 42$

References..................................................................................................................................... 44 


\section{EXCHANGE RATE UNIFICATION}

Exchange rate reform in developing countries is motivated by the related goals of improving balance-of-payments sustainability and increasing exports. The objectives are usially to remove distortions in relative prices and choose policies almrd depreciating the real exchange rate in order to make expcrts more competitive.

For non-Franc Zone Sub-Saharan African countries where the black market premium on foreign cxchange is high--typically exceeding a hundred percent and often in excess of three and four hundred percent--1t is argued here that these goals are tantamount to reducing this premium. Essentially, the black market premium functions as a tax on exports. In order to deprectate the real exchange rate and stimulate exports, it must be lowered.

In fact, recent conditionality negotiated between the World Bank and IMF and many Sub-Saharan African countries, e.8., Ghana, Nigeria, Sierra Leone, 2 mbia, Is interpretable as directly impinging on the unification of officlal and black market exchange rates. The recent trend towards official floats in developing countries (Quirk et al. (1987)) often has as an explicit goal, the absorption of black markets and minimizing black market premia on forelgn exchange. It has been recognized that these goals must be achieved by eliminating distortions in economic incentives, not through unenforceable legislation or costly survelliance.

The importance of the black market lies in the fact that the marginal cost, or implicit resale value, of forelgn exchange is determined on this market. Initial conditions include an official market with a managed (fixed) rate, which 18 rationed, and a black market, where the 
currency floats freely and foreign exchange is at a premium. In contrast to the usual description of such dual markets, e.g., Lizondo (1984), Dornbusch (1986), Comestic currency in the dual regimes of Africa is not convertible for elther commercial (trade) or capital (financial) transactions at the official exchange rate. As a result, the black market rate applies explicitly or Implicitly to both sets of transactions.

"Unification" in this paper w11 refer to the process whereby the black market prenitum is lowered and the official and black market rates brought close to each other. Complete elimination of the premium on an ongoing basis will require the removal of all restrictions on capital and commercial transacticns. In practice, except for the Gambia, African countries that have floated their currencies have done so only commercial transactions with capital controls retained for outwa $i, \ldots$ lows, e.g., Nigeria, Zaire. For the purposes of this paper, this response will count as unification. Whether or not capital controls, which are a distortion in intertemporal trade, should be relaxed depends on 18 sues beyond the scope of this paper, e.g., the speed and extent of domestic financial liberalization, and other sequencing 18 sues (Edwards and van Wijnbergen (1983)). When currencies have been floated on the trade account with capital controls retained, arbithge possibilities have kept subsequent premia small, 10-15 percent, especially when compared with their substantial initial levelo. 11

While there are compeling equity and efficiency arguments in favor of unifying official and black market exchange rates, there is a second issue. Unification could have important fiscal Implications, the direction of which depends upon whether the government on balance sells (e.g., Nigeria) foreign exchange to, or buys (e.g., Ghana, Sierra Leone) 
foreign exchange from the private sector. In the net seller case (Nigeria), unification would imply a reversal of real income transfers back to government from the private sector. In the net buyer case, unification could imply a substantial 1088 of revenues from exports. The magnitude of the flocal effect in either case depends upou the prevaling level of the premium. Since Nigeria 18 in a small minority, this paper will concentrate on the more common net buyer case, noting exceptions to results when approprlate.

in two recent instances, Sierra Leone and $2 \mathrm{ambla}$, there was a big surge in inflation upon attempted unification of offictal and black market rates by adopting market-determined official rates. Such surges in Inflation have high social and political costs, and cotid create policy reversals, thereby damaging the credibility not only of the reform, but also of loan conditionality. This paper explains such surges in postunification inflation by the fiscal effects of unification.

Essentially, there are strong links between exchange rate and fiscal reform. Whilc the allocative goal of stimulating exports requires that the black market premium be lowered, this is in conflict with a revenue goal. Given the limited menu of avallable tax instruments, the black market premium 18 an impurtant implicit tax, so that there is a trade-off between the premium (tax on exports) and inflation (tax on domestic money) in financing the fiscal deficit. Therefore, unifying official and black market exchange rate could raise inflation substantially even if the level of real government spending stays constant, as the lost revenues from exports are replaced with a higher tax on money. To the extent that government spending can be justifiably reduced and other taxes justiflably raised, this conflict is naturally lessened. Otherwise, the increase in post.unffication inflation will be permanent. 
A crucial step in understanding the trade-off between the premium and inflation involves identifying the determinants of the premium, which is endogenous. These determinants include flocal, monetary and exchange rate policy, asset prefrences and the terms of trade. Accordingly, the paper first develops the links among black market premia, real exchange rates, unification and inflation. It presents some recent country experiences on unification, using this as a basis for proposing transition guidelines and a changed emphasis in loan conditionality.

II. REAL EXCHANGE RATES, INFLATION AND THE BLACK MARKET PREMIUM

There are three new results: first, in order to depreciate the real exchange rate and stimulate exports, the black market premium must be reduced; second, there is a trade-nff between the premium and inflation in financing the fiscal deficit; and third, unification of official and black market exchange rates without a matching fiscal response will ralse inflation even if real government spending remains unchanged. The higher the premium to start with, the bigger will be the surge in the rate of Inflation upon unification. 21

An important idea is that the marginal, or Implicit, or opportunity cost of foreign exchange is the freely floating black market rate. This rate is at a premium relative to the arbitrarily-set official rate, at which there 18 excess demand for forelgn exchange. Rather than deplete its scarce foreign exchange reserves in order to "defend "the fixed, official rate, the government chooses to ration tise official market through capital controls, import licenses and other means, thereby excluding capital transactions and a large fraction of bonafide comercial 
transactions. The black market rate therefore adjusts to equilibrate demand and supply in the forelgn exchange market as a wholes foreign exchange allocated at the official rate is implicitly or actually re-sold. The basic structure of the economy and assumptions are now outlined. There is currency sub. " stion (Calvo and Rodriguez (1977)) with domestic residents holding two non nterest bearing assets, domestic money (generically called "pesos") and foreign money ("dollars"). Since there 18 an asset demend for dollars, the portfollo balance approach to exchange rates is relevant, implying that the stocks of pesos and dollars matter for exchange rates, not just current account flows. The dynamics of the stock of pesos is influenced by the money-financing of the fiscal deficit, and of dollars, by the current account.

The official exchange rate, e (pesos per dollar) serves effectively as a tax on exporters. For simplicity, the government spends only on imported goods and interest payments on historically contracted foreign debt. It buys foreign exchange from the private sector at the arbitrary rate, e. The existence of a flscal deficit then allows a simultaneous examination of the inflation tax on pesos (defined below) and the tax on exports by a choice of $e$.

The official foreign exchange market is rationed by capital controls and restrictions on commerclal transactions. We assume that this is done in such a way that there is no official net foreign asset accumulation. 3/ Thus, a fraction of private sector exports is surrendered to the government at rate e. The government uses this to partly finance Its own spending, returning the balance to the private sector (through import licenses and administrative allocation) also at rate e. The government chooses an official rate of depreciation, $\Delta e / e z 0$. 
The rationing scheme is thus a redistribution within the private sector cuupled with a net tax transfer to the government. Owing to rationing, there is a premium on dollars in the black market, where the exchange rate is bze. Domestic currency is freely convertible in the floating black market at rate b, the marginal cost of foreign exchange.

\section{Real Exchange Rate 41}

There is no capital in our oimplified economy, and labor is fully employed. Two goods are produced: an export good, $X$, with dollar price $p_{x}$.

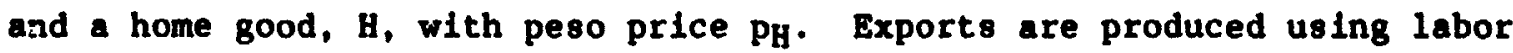
(L) only, with a simple constant-returns-to-8cale (CRS) technology, $X=L$. On the other hand, home goods are produced using labor and intermediate Imports (011) also with a CRS Cobb-Douglas technology. Home gonds include all goods and economic activity that do not contribute to the supply of tradables. This would, in the African context, Include comerce, e.g., the distribution and market ing of imported consumer goods, and highly protected manufacturing that thrives on cheap imports via licenses at the official rate (see also Krueger (1974)).

Exports are either surrendered at rate e or smuggled out at rate b, with increasing marginal costs of smuggling. Exports are divided between the official and black markets in such a way that marginal returns are equal in both markets, 1.e., $b p_{x}-M C S=e p_{x}$, where MCS is the marginal cost of smuggling that increases with the volume of smuggled exports. Owing to the production technology, it follows that in equilibrium, epxw, where $w$ is the peso wage.

Imports are priced at their marginal cost, b (the dullar price of imports is unity). Owing to the Cobb-Douglas technology, H=L $a^{1-a}, a$ between 0 and 1 , where $I$ is imports, so that in equilibrium, $p_{H}^{-k} . w^{a} a^{1-a}$, 
where $k$ is a constant depending upon $a$. Since waep $p_{x}$, the real exchange rate RER, or the relative price of exports, is?

$$
\operatorname{RER}=e p_{x} / k\left(e p_{x}\right)^{a} b^{1-a}=k^{-1}\left(p_{x} / \phi\right)^{1-a} .
$$

where $\beta(b / e)$ is the black market premium (actually, the premium plus 1 ). A rise in RER (real depreciation) will increase the incentives to produce exports. It 18 obvious from eq. (1) that, cet. per., this will happen if and only if the premium, f, falls. Fig. 1 summarizes this graphically, PPE denoting the production possibilities between $H$ and $X$. The shape of the production possibility curve is derived in Appendix 1.

Fig. 2 shows how total exports, xopt, at premium $\phi$, are distributed between the black market (OY) and offlcial market (YXOPt).

PROPOSITION 1: In order to depreciate RER and stimulate exports, the black market premium on foreign exchange must be reduced.

\section{I1: 'lation Tax and Exports Tax 51}

Let $M$ denotc the stock of pesos and $F$ of dollars held in private portfolios. Given earlier assumptions, 8 desotes government spending on imports and interest payments on foreign debt and 18 fixed in dollars. Taxes, $t$, are also fixed in dollars. The pesc deficit, e.( $8-t)$, is financed by printing pesos. Since there 18 no net official accumulation of dollars, it follows that the change in the stock of pesos, $\triangle M$, is given by:

$$
\Delta M=e \cdot(B-t),
$$

with the dollar deficit converted into pesos at the officlal exchange rate. Thus, $\Delta M$ is endogenous through the budget and is also influenced by official exchange rate policy. Eq. (2) can be rewritten: $\Delta M / e=(8-t)$, or $(\Delta M / M) \cdot(M / e)=(g-t)$. The proceeds from the inflation tax, or seignorage, 
$-8-$

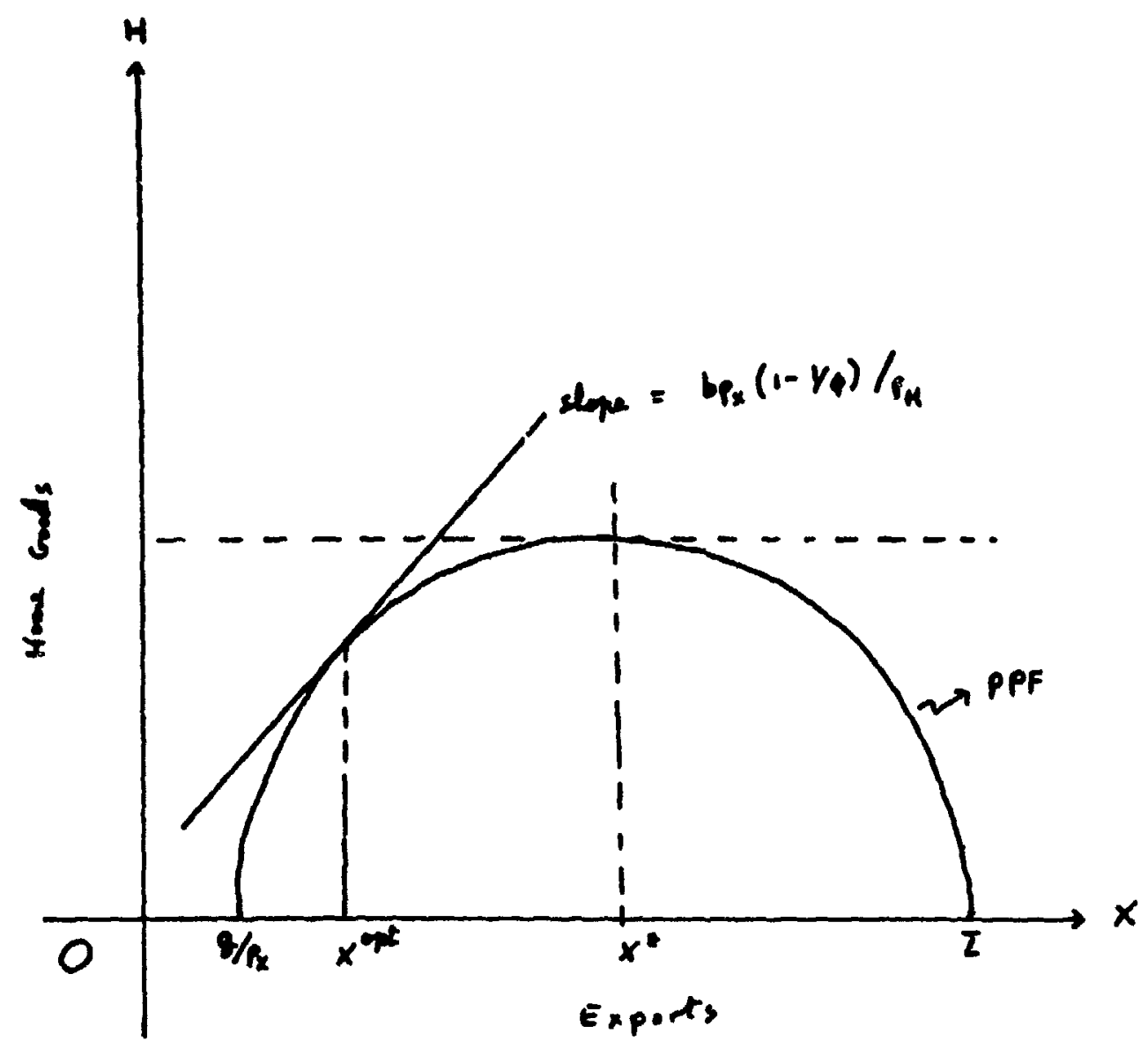

Fig. 2: Steady-stat PPF between home goods and exports

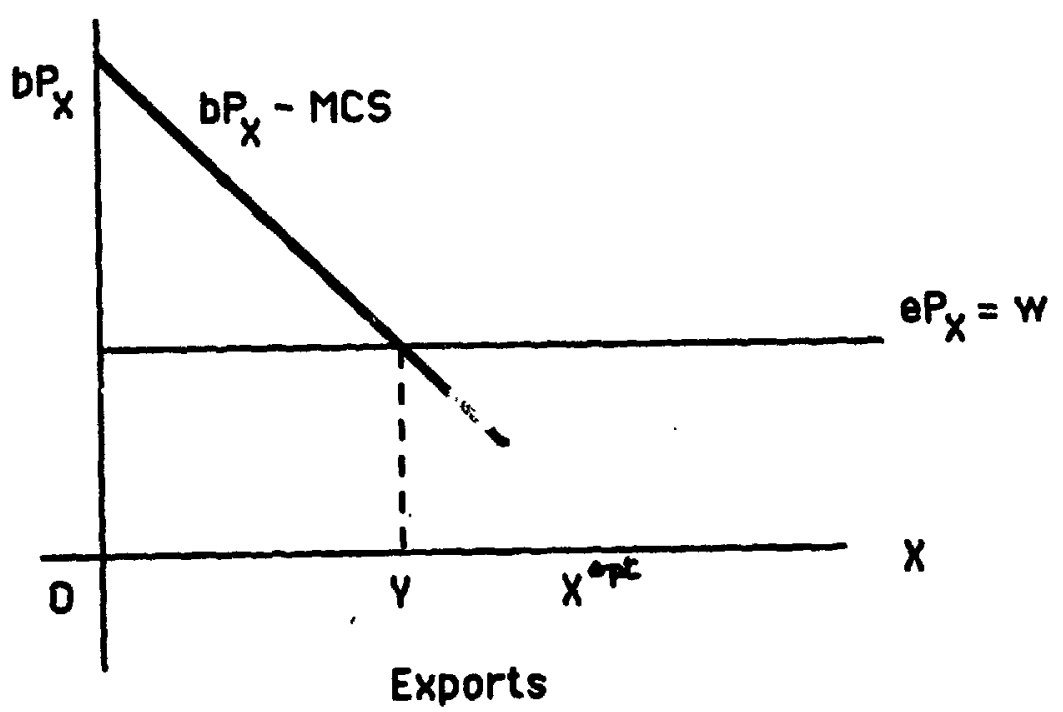

Fig. 2 : smuggling of Exports 
$(g-t)$, is the product of two numbers, $(\Delta M / M)$, or the growth rate of money, and $(M / e) \equiv m$, wich we loosely call the real money otock. By analogy with other taxes, therefore, the revenue from the inflation tax is given by the tax rate, $(\Delta M / M)$, times the base of the tax, $m$.

A property of such models is that in steady state, $\Delta M / M=\Delta e / e, 80$ that the rate of the Inflation tax in steady otate is the same as the rate of depreciation of $\theta$, which 18 also the rate of inflation. Hence, selgnorage in steady state is given by $m(\Delta e / e)=(g-t)$. However, the relevant capital 1088 incurred by the privere sector as a result of the Inflation tax is $(M / b)$. De/e in steady state, since $b$, and not $e$, is the marginal cost of foreign exchange. Likewise, the relevant burden from conventional taxes is et/b. Since the private sector's 1088 is the government's gain, it follows that the residus in ateady state must be the Implicit tax on Imports via $\phi$

$$
8=m \cdot \frac{\Delta e}{e}+t=\frac{M}{b} \frac{\Delta e}{e}+\frac{e t}{D}+g\left(\frac{b-e}{b}\right)
$$

The tax on exports is the last term on the R.H.S. of $(3), g((b-e) / b)$, which can $a 180$ be written $g(1-1 / \phi)$ ince $\phi=b / e$. Thus, if $\phi>2$, 1.e., the black market premium exceeds 100 percent, not uncommon in Africa, th1s tax finances upwards of 50 percent of government spending on imports and forelgn interest payments !

\section{Trade-off Between Inflation and Premium}

A portfolio balance equation 18 needed to complete the system. Above, the dynamics of $M$ were discussed. The dynamics of $F$ are determined by the current account:

$$
\Delta I=p_{X} X-B-I,
$$


since net offictal dollar accumulation 18 zero. $6 /$ private sector wealth is given by $W=(M+b F)$, where $F$ is converted to pesos at the black market rate, $b$. The share of $M$ and $F$ in $W$ are determined by pcrtfollo balance considerations. Let $\lambda$ be the fraction of $w$ held as pesos, M, 1.e., M- $\lambda w$. $\boldsymbol{\lambda}$ depends upon the differential rate of return between $M$ and $F$. Since there are no interest rates in this model, this is just the black market rate of depreciation, $\Delta b / b$. As $\Delta b / b$ rises, $\lambda$ falls, 1.e. dollars become more attractive. Since $\phi \equiv b / e$, ic tollows that $\Delta b / b=\Delta \beta / \phi+\Delta e / e$. Further, in steady state, with a given premium, $\Delta b / b=\Delta \in / e$.

The dynamic equations of the system are (2), (4) and the portfolio balance equation, which is an implicit equation in $\Delta / / \phi$. Solving the system for $(m, F, p)$, it can be shown that the determinants of the steady state premium $\phi^{*}$ are as follows (see Pinto (1987b)):

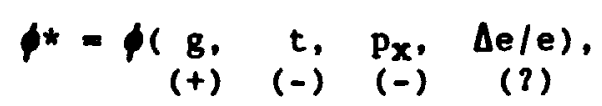

where the signs of the comparative statis expressions are shown below each determinant. A rise in $\mathrm{g}$, or fall in $\mathrm{t}$, will increase the reliance on the Inflation tax. For a given rate of steady state inflation, De/e, this will increase the steady state level of $\mathrm{m}$, thereby requiring a rise in the premium, $\phi$, to restore portfolio balance. Likewise, a rise in $p_{x}$ (terms of trade improvement) will, cet. par., ease the supply of dollars, lowering the premium on foreign exchange.

If the rate of deprec ition $\Delta e / e$ is changed, however, the effect on the premium is ambiguous. The intuition 18 as follows: First, recall

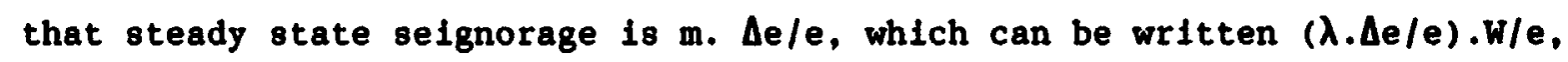
since, $m=\lambda . W / e$. Thus, the proceeds from the inflation tax depend upon the share of pesos in financial wealta, $\lambda$, the rate of inflation, $\Delta e / e$, and 
financtal wealth. We shall refer to $(\lambda . \Delta e / e)$ as the unit inflation tax. Now suppose $\Delta$ ele is raised. Th1s will raise the differential rate of return between pesos and dollars, making dollars more attractive. This by Itself would raise the premium. At the same time, however, since the real deficit, $(g-t)$, Is given, a smaller peso base is required for the inflation tax, creating the ambiguity. It turns out that whether or not rises depends upon the inflation elasticity of the share of domestic money in wealth, $\lambda$. If this is 1088 than unity, ralsing $\Delta e / e$ will ralse the unit Inflation tax and lower the premium. Otherwise, the premiun will actually rise. Thus, an acceleration of the official rate of depreciation ts not guaranteed to lower the premium. The outcome depends cruclally on the inflation elasticity of the demand for pesos.

The inflation elasticity of the demand for pesos rises with the rate of inflation, 1.e., the propensity to shift into dollars to avold the inflation tax becomes stronger as inflation rises. This results in a seignorage Laffer curve, with the unit inflation tax rising for inflation rates below the seignorage-maximizing level of inflation and falling above 1t. The very same reasoning in conjunction with the previous paragraph ylelds a u-shaped curve linking the steady state premium and inflation. This is shown in Fig. 3.

In Fig. 3, the steady-state premium is plotted on the Y-axis, and the rate of inflation, which is also the chosen rate of official depreclation, $\Delta e / e$, on the $X$-axis. The two $u$-shaped curres, BB and CC graph the relationship between the premium and inflation tax for two different levels of government spending, $81>80$. For inflation rates between 0 and $A$ on the $X-a x i s$, the Inflation elasticity of peso demand (denoted by $\eta$ ) 18 less than one. Hence, a rise in the rate of inflation 
$\frac{E}{\frac{E}{D}}$

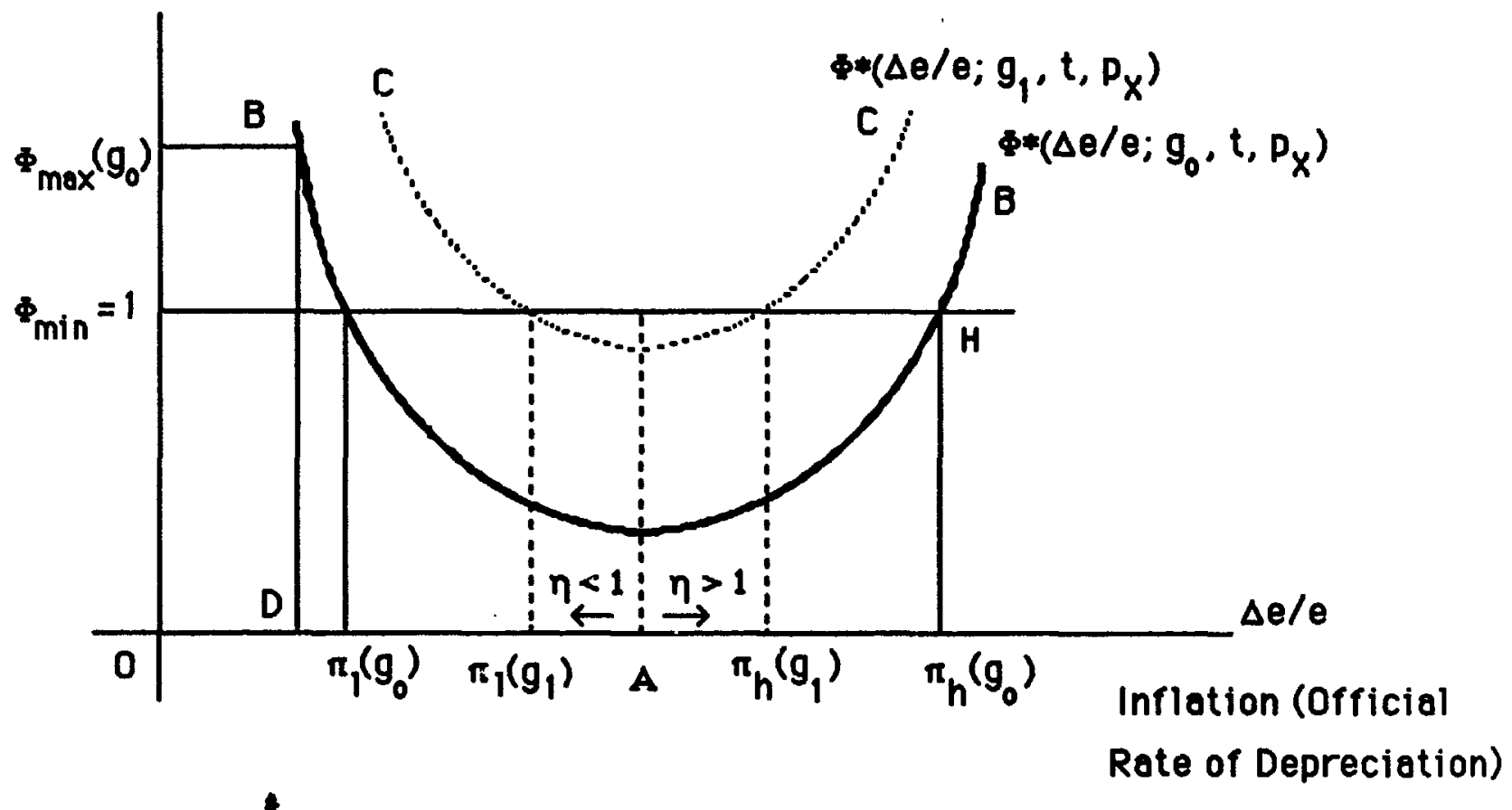

Fig. 3 : Steody-Stote Inflation and Premium

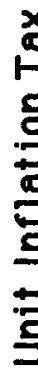

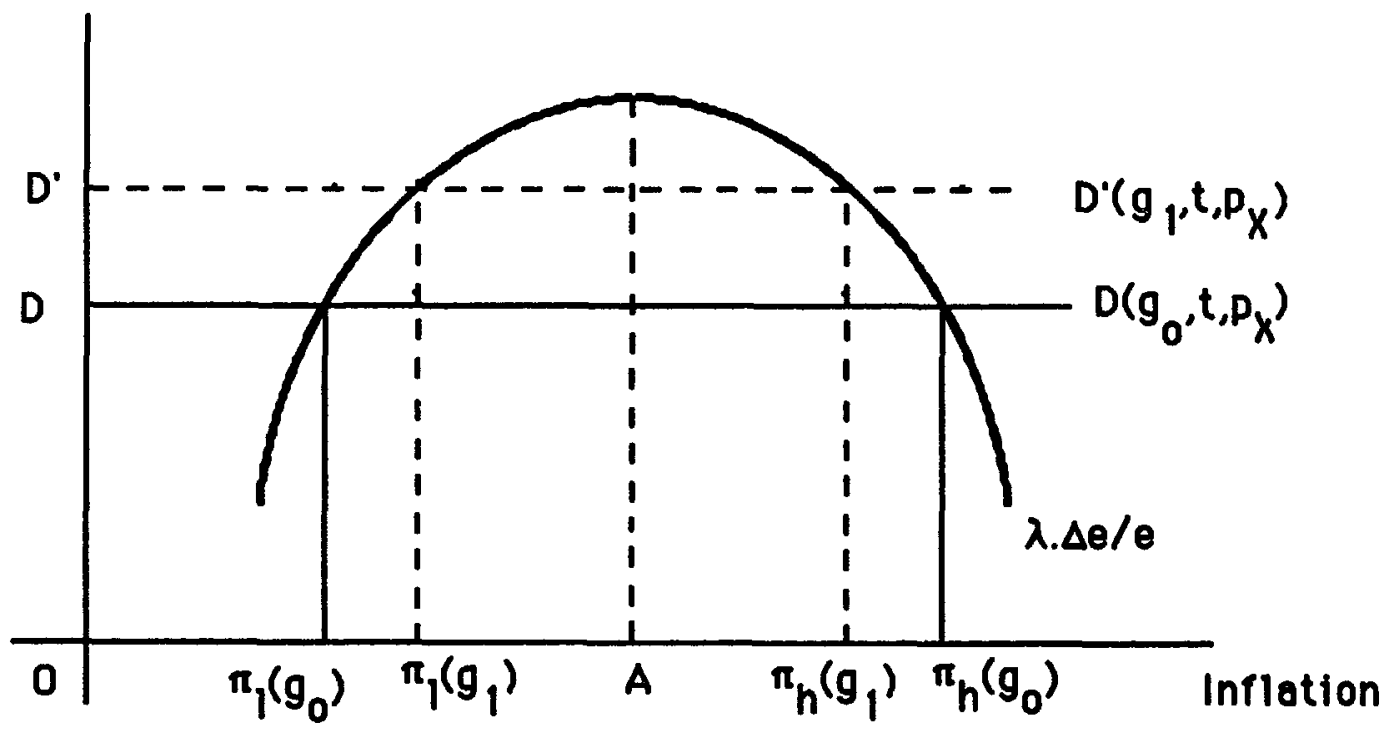

Fig. 4: Dual Equilibria Upon Unification 
raises the unit inflation tax and lowers the steady-8tate premium, $\phi^{*}$. Thus, to the left of $A$, a rise in the tax on money for given $g, t$ and $p_{x}$ enables a lower tax on exports, embodying a trade-off between the two taxes. To the right of A, exactly the opposite is trues a rise in $\Delta \mathrm{e} / \mathrm{e}$ will raise $\phi^{*}$ because $\eta>1$. A trade-off is not possible. OA 18 the seignorage-maximizing rate of inflation $(\eta-1)$.

Now suppose real government spending is ralsed from Bo to $\mathrm{g}_{1}$. The curve shifts upwards from the solid 1ine, BB, to the dotted 1ine, CC: for any chosen $\Delta e / e$, a higher tax on exports is required to finance the higher deficit. Assume that $g=B_{0}$, 80 that $B B$ is the relevant curve. $\phi_{\max }\left(8_{0}\right)$ is defined as the maximum level of the premium that will enable the government to meet its dollar requirements from surrendered exports, since from FIgs. 1 and 2 , it is obvious that these will fall as the premium rises. Likewise, there is a minimum level of the premium, $\phi_{\text {min }}$, compatible with the above system. In the dual regime, owing to rationing, it is desirable that $\phi^{*}$ exceed one. We also assume that it is possible for the government to finance the entire deficit by inflation, should it choose to. This implies the elimination of the tax on imports or $p^{*=1}$. Thus, $\phi_{m i n}=1$ and the relevant range of inflation rates for a tradeoff with $g=g_{0}$ is (D, $\pi_{1}\left(8_{0}\right)$ ) as shown in $F I_{g} .3 .7 /$

A terms of trade improvement (rise in $p_{x}$ ) affects $\Delta F$ favorably, hence lowers $\phi^{*}$, for given $g, t$ and $\Delta e / e, a$ rise in $p_{x}$ lowers the u-shaped curves in Fig. 3, raising $\phi_{\max }$ and lowering $\pi_{1}$. A fall in $\mathrm{p}_{\mathrm{x}}$ has exactly the opposite effects.

PROPOSITION 2: Assume that, for given $B, t$ and $p_{x}$, the rate of inflation In the dual regime is chosen to lie in the interval (D, $\pi_{1}\left(8_{0}\right)$ ) with $8=8_{0}$. In other words, there is a trade-off between $\Delta e / e$ and to start with, and 
$\eta<1$ (a necessary condition for the trade-off). Then, if the pero 18 floated overnight (official rationing is eliminated and the rate of depreciation endogenized, or determined by market forces) post-unification inflation will rise permanently.

In fact, the rate of inflation that will emerge is $\pi_{1}\left(8_{0}\right)$. If 8 were equal to the higher level, $g_{1}$ corresponding to $\mathrm{CC}$ in $\mathrm{Fig} .3$, the higher rate $\pi_{1}\left(g_{1}\right)$ would be the post-unification inflation level. The proof of PROPOSITION 2 is obvious from Fig. 3.

F1. 4 11lustrates the two possible inflation equilibria upon floating the currency. The inverted u-shaped curve is the unit inflation tax. The horizontal line DD indicates the level of required unit inflation tax for given fiscal policy and terms of trade. $\pi_{1}\left(g_{0}\right)$ and $\pi_{h}\left(8_{0}\right)$ shown in Fig. 4 correspond exactly to those in Fig, 3, as does the point A. For 8=g1, D'D' applies. 8I

We have so far considered the case where the government is a net buyer of foreign exchange from the private sector. What about countries such as Nigeria, where the opposite holds? In the dual regime, a premium on dollars implies a real income transfer from the government to the private sector. Thus, overnight floating that unifies official and black market rates will eliminate this transfer, improving the budgetary situation. Therefore, the horizontal line DD will move downwards upon unification, actually lowering $\pi_{1}\left(8_{0}\right)$ and lowering post-uniffcation inflation.

A final comment in this section: the determinants of the steadystate premium (see eq. (5)) in the dual regime do not include the level of the officlal exchange rate, $e$, but only its rate of depreciation, $\Delta e / e$. This implies that discrete, one.-shot devaluations, say every 6 months, will reduce the premium only temporarily. As we shall see in the next section, 
there is much empirical corroboration for this established result (Dornbusch et al. (1983), Lizondo (1984), Pinto (1986)), Such devaluations will reduce the premium permanently only in the uninteresting case where the real deficit is zero. Otherwise, the effects will be strictly temporary in the absence of more fundamentsl changes in fiscal and monetary policy, since devaluations do not affect growth rates. However, devaluations are valuable in opeeding up adjustment when they accompany reductions in the real deficit, and as a signal of intent to introduce more basic r.forms.

III. COUNTRY EXPERIENCES WITH UNIFICATION $9 /$

\section{Ghana}

Between 1975 and 1983, the Ghanaian economy exhibited the following features: large flacal deficits financed by printing money; strict foreign exchange rationing, with the black market rate applying Implicitly to all foreign exchange transactions; asset demand for dollars as a hedge against inflation; Inflation and the price level strongly correlated with movements in the black market rate; and the black market premium serving purely as a tax-subsidy scheme.

The black market premium was generally in excess of 500 percent, attaining a record level of over 2000 percent in 1982. Average inflation exceeded 50 percent per year, with triple-digit levels in 1977, 1981 and 1983. Reported real per capita income fell by 30 percent between 1970 and 1982, and production, including the key exports, cocos and gold, fell sharply. Rather than correct flocal or exchange rate policy, external balance was forced by rationing the official forelgn exchange market 80 
that the official current account was 8 mall relative to other African countrles, never exceeding 1.5 percent of GDP (see Pinto and van Wijnbergen (1987)).

In April 1983, Ghana adopted an IMF - supported Economic Recovery Program (ERP). The ERP initiated fiscal and exchange rate reform, with huge export premia and import surcharges causing a de facto devaluation of roughly 800 percent of the Ghanalan cedi $(\downarrow)$. This was followed in October 1983 by an actual devaluation of 990 percent - a record perhaps, for the blggest one-shot devaliation - with the exchange rate being adjusted from $2.75 \$ / \$$ tr $30 / / \$$. The system of premia and surcharges was simultaneously scrapped. The black market rate at the time was roughly $90 \$ 1 \$$.

Subsequent measures included an export retention scheme: non-cocoa exporters could keep some fraction of their earnings for debt service and approved imports. More significant was the re-introduction and formalization in October, 1985, of the special import license scheme - the SIL market - whereby licenses would be freely issued to those who wished to bring imports in through the black market, provided they paid the requisite taxes. The creation of the SIL market conferred recognition on the black market as a channel for trade flows and source of dollars, being an Important step in unification.

Through a serles of discrete devaluations, the official exchange rate had by September, 1986 reached a level of $90 \$ / \$$, but was still at a substantial discount relative to the SIL and black markets, necessitating rationing. It was therefore declded to split the official market into two tiers: a fixed rate tier, with an officially set rate, and an auction for raw materials and inputs oily. The resultant segmentation of transactions 
represented the continued taxation of cocoa and subsidization of petroleum, since domestic prices in both cases were to be set at the fixed tier rate. The fixed rate and auction markets were unified at the auction rate in March, 1987. The next step is the merging of the auction and SIL markets, by gradually permitting consumer goods into the auction. Capital controls have been retained.

\section{Assessment of the Ghanaian Response}

Ghana's stratezy has been one of gradual reduction of flocal deficits combined with widely-spaced, but large devaluations of its currency, the cedi. At the same time, it has sought to re-establish its International credit rating and launched a tax and tariff restructuring program. The measures after September, 1986, may be described as the gradual removal of forelgn exchange rationing coupled with the unification of the official, auction and SIL markets at a free market rate.

Instead of its chosen path of discrete maxi-devaluations accompanying flscal reform, Ghana could have inftially accelerater the rate of depreciation of the cedi above prevailing rates of inflation in order to depreclate the official real exchange rate.10/ This response could have been destabilizing. Such acceleration could also have been motivated by a desire to respond to the considerable black market premium. Avallable estimates (PInto (1986)) suggest that when the ERP was launched, prevalling rates of inflation in Ghana exceeded the seignorage-maximizing rate of inflation, implying that the inflation elasticity of the demand for cedi balances exceeded one. An acceleration therefore, could have backfired, raising the premium (recall Fig. 3 ). 
The experience of Bolivia (Sachs (1987), Kharas and Pinto (1987)) suggests that this is no theoretical curiosity. In the three years preceding 1983, the rates of inflation in Bollvia were 47, 32, and 124 percent, respectively, not unlike those in Ghana. In 1983, the Bolivian inflation rate was 276 percent. The black market premium, however, was much lower than in Ghana. In the last quarter of 1984 , with the average premlum having more than doubled since 1980-81, there was considerable pressure to unify exchange rates, although the premiun at 2.95 was low by Ghanaian standards. It was decided to use nominal exchange rate policy to minimize the black market premium. The erroneous argument that the equilibrium nominal exchange rate was a weighted average of the official and black rates, and that the official rate be devalued towards it, resulted in a rule that directly linked official depreclation to the black market premium. Official depreciation jumped to 350 percent in the last quarter of 1984 , and 455 percent in the first quarter of 1985 . The premium fell at first, but with the black market rate responding, it rose again, resulting eventually in 496 percent inflation in the first quarter of 1985 , an annualized rate of 126,000 percent I

The Bolivian hyperinflation 1llustrates that targeting the premium through exchange rate policy alone could be costly. It also suggests that there is a sequencing issue in the introduction of flocal and exchange rate reform, with fiscal reform coming first. An important reason is that fiscal reform takes longer and is more difficult to implement, so that it takes time to become credible. On the other had, a change in exchange rate policy can literally be undertaken overnight, via a central bank bulletin. Given the initial conditions in Ghana, the measures taken soon after launching the ERP are defensible, assuming that there were both economic and political cbjections to getting rid of import licensing and 
floating the cedi immediately. Economic objections would have pertained to the fiscal problem, the lack of documented experience with floats in developing countries, the policy credibility problem and the suitability of institutional mechanisms, in view of the problems with the banking sector. Political objections would have centered around a reluctance to get rid of administrative allocation, which is commonly perceived in developing countries as a way of ensuring an optimal allocation of foreign exchange. Once the SIL market was created, however, the gradualism with which exchange reform has been proceeding must defer to political, instead of economic arguments. There are no economic reasone for not having removed all restrictions Immediately on comercial transactions thereby merging the fixed rate, auction and SIL markets. If there is a desire to restrict the importation of certain goods, this could be better achieved through an appropriate tax system. Lastly, there is the question of what permanent arrangement will be adopted after the three markets are unified. The current proposal is to continue with the auction system. The role of comercial banks and the possibility of an interbank float need to be considered as a serlous alternative (see Pinto and van Wijnbergen (1987) for a discussion of this issue).

\section{Nigeria 111}

By 1981, oil had become the key determinant of Nigeria's real Income, external terms of trade, creditworthiness, government revenues and forelgn exchange earnings. The oil sector had come to account for 22 percent of GDP, 81 percent of government revenues and 96 percent of exports. 121 
The black market premium was fairly steady intil the ofl glut in 1982, when three things happened, first, the price of oll fell far below expectations; second, government spending remained roughly the same so that the reliance on the inflation tax for financing the flocal defici: Increased considerably (see Table 1); third, foreign exchange rationing was Intensified to deal with excess demand for dollars at the official rate. The black market premium - defined as the ratio of the black market to the official exchange rate - continued growing. Implying In particular that the Nigerian nalra was depreclating faster on the black market. After 1984.3, it stabilized. These developments colncided with the declining real price of oil, as can be seen from Table 1.

Reductions in real government spending and official imports are efficacious in reducing the premiun, as seen in section II. In substantial measure, fiscal austerity since the end of 1984 exploited this possibility. The deficit/GDP ratio and the growth rate of nominal money fell sharply as a result. The exchange rate regime, however, remained the same with the exception of a faster rate of depreciation, as is evident from Table 1. 13/ The fiscal burden of rents was substantial: given an illustrative import program of U.S. \$ 3 billion and a black market premium anywhere between $2 \mathrm{w} / \mathrm{S}$ and $3 \mathrm{w} / \mathrm{S}$ during the import 1 icensing era, rents were between N6 and 49 billion, a significant fraction of annual GDP at roughly $N 70$ billion ( $N$ denoting "nadra"). In addition to the inequity inherent in this unearned income transfer, the Import licensing system was also inefficlent: it enabled economic activity unviable with a more realistic exchange rate, encouraged businessmen to invest resources in the pursult of rents and placed an enormous administrative burden on civil servants. 14 / 
Table 1: NIGERIA-DEFICIT FINANCE, INFLATION, AND PREMUM

(Quarterly Average8)

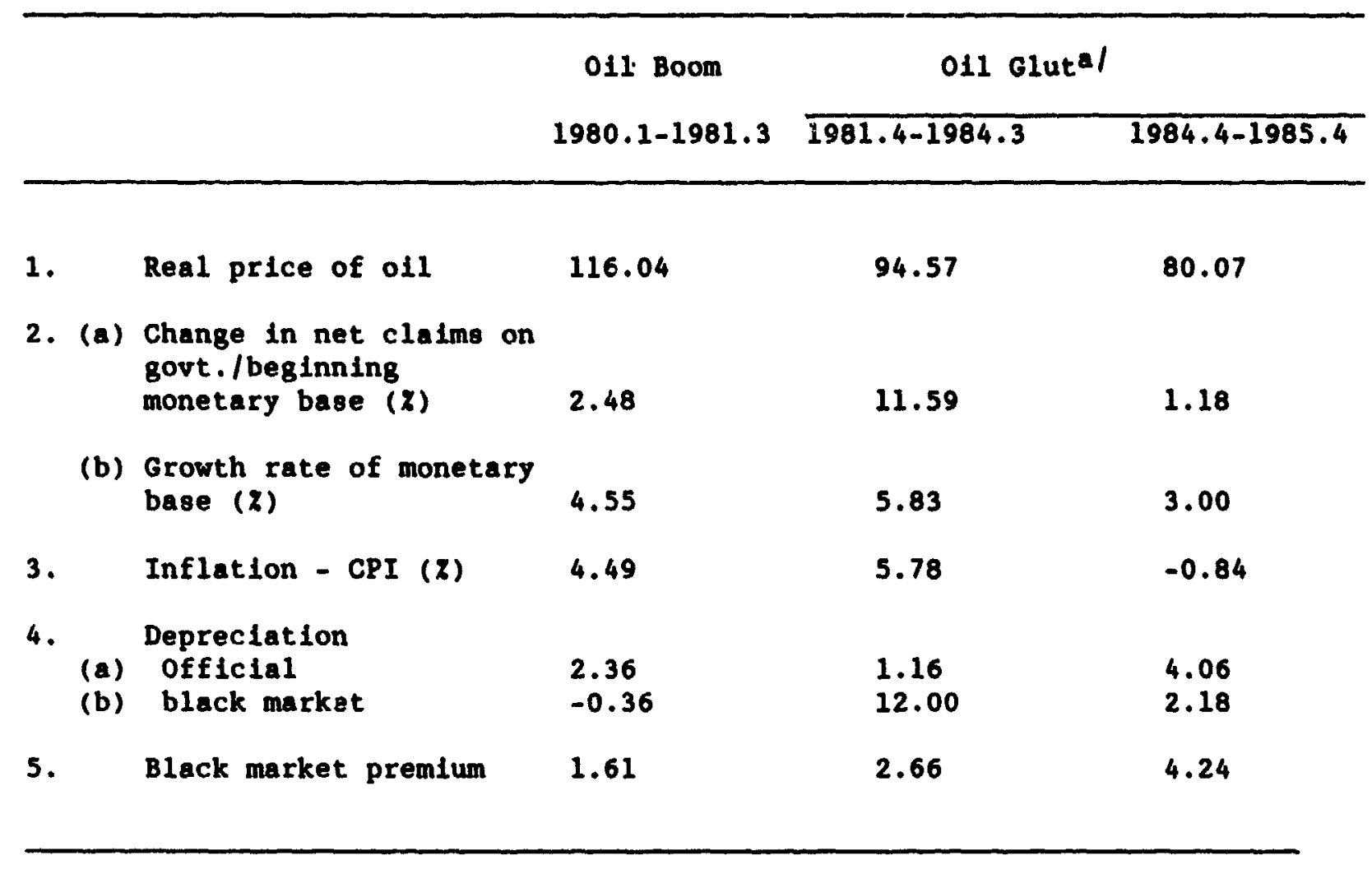

af The second sub-perlod, 1984.4 to 1985.4 , refers to the period of flocal austerity.

Sources and Notes:

1. Real Price of 011: Nigerian bonny 1ight petroleum prices deflated by U.S. WPI $(1980.1=100)$ oll prices: EPD, IBRD; U.S. WPI: IFS, IMF.

2. Net claims on Government: line 32an, IFS; Monetary Base: Reserve Money + Net Claims on Government by commercial banks (1ines 14 $+22 a-26 d)$, IFS, IMP.

3. CPI, official exchange rate (period averages): IFS, IMF.

4. Premium = black market rate/official rate. Black market rates from World Currency Yearbook. 
Another compelling reason to unify was the budget, moving to a market exchange rate would substantially increase the nalra revenues from the sale of oll dollars to the private sector. On September 26, 1986, Nigeria held its first foreign exchange auction as a prelude to establishing a floating interbank market, simultaneously abolishing the Import 11cense system, a step of immense symbolic and real value.

Subsequent movements in prices and exchange rates in Nigeria have lald to rest two common misconceptions regarding dual regimes of the type discussed in this paper. The first is the ldea that in dual regimes, the "equilibrium" exchange rate is some average of the official and black market rates, with the weights equal to the export--or import-- shares of these markets. By this argument, the equilibrium exchange rate should have been close to 1.5 nalra to the dollar, since 95 percent of Nigerian exports are 011, whose recelpts went through the official channel. In practice, an exchange rate emerged that was close to the one in the black market, where the rate was between 4 and 5 nalra to the dollar, and which was invariably dismissed as "thin". Analytically, this is not surprising owing to resale-there was a virtual secondary maricet in import 1icenses--and the fact that prices are determined on the margin.

The second misconception is that if unification involves a substantial one-shot depreciation of the official rate, the effects will be inflationary. This in itself will not be inflationary, since the more depreclated black market rate is already reflected in domestic prices. Postnification inflation depends rather on the fiscal implications of unffication and subsequent other changes in fiscal and monetary policy.

In conclusion, one can make a strong case for the Nigerian naira having been floated earlier, especially in view of the salutary fiscal effects. The delay must be attributed to political constraints, the Nigerian 
government had demonatrated fiscal discipline aince 1984, with a proven track record in 1ts ability to control spending and pay attention to budget constraints. Nevertheless, once the decision to flont was made, the Interbank float was introduced with commendable professionalism and openness. Above all, care has been taken to malntain confidence in the domestic banking gyotem, and in living up to the commitment that private capital reflows from abroad would be treated on a confidential, "no questions" bsols. These measures will go a long way in establishing the interbank floating market as a credible and effective exchange rate system.

\section{Zalre}

Following a perlod of transition, which lasted about five months, Zaire adopted a unified floating exchange rate regime in February, 1984. During the transition, dual official rates were implemented as a prelude to unification. The float has been in existence for over three years, representing the longest-1ived experience in Sub-Saharan Africa with floating regimes. Excluding the discontinued auctions in Slerra Leone and Uganda, Zaire is also the first Sub-Saharan African country to officlally float its currency: we note importantly that before the transition, which began in September, 1983, Zalre had the usual, Implicit dual regime, with the marginal cost of forelgn exchange determined on a floating, black market.

Since zaire is in a sense a success story, this case study will describe how the transition to the float was managed. In contrast to other experlences, e.g., Ghana, Nigeria, the transition was smooth and brief, We shall therefore focus almos exclusively on this aspect of the zairian experience. 


\section{Inteial Conditions}

Table 2 summarizes key economis data on zalre from 1980-85. Zaire has had a history of high inflation as evidenced in Table 2 by the growth rate of base money, the CPT. and currency depreclation. In the three years preceding the float 1981-83, moreover, the average black market premium was roughly the same, Implying that black market depreclation matched official depreciation: the dip in the premium in 1983 is due to the first phase of the float, which was introduced in September, 1983. This confirms the established result that perlodic devaluations will not reduce the black market premium unless accumpanied by more fundamental reforms. Thus, the fiscal deficit/GDP ratio actually increased between 1980-82, coinciding with a steady deterioration in the terms of trade. Both derelopments, the first a policy variable and the second an exogenous shock, would have exerted upward pressure on the premium.

In terms of exchange arrangements, the currency of zaire, the zaire, had had an adjustable peg against the SDR since March, 1976. Foreign exchange was administratively allocated for trade and current transactions and there were, and are, capital controls.

\section{Transition to Unifled Float}

Following a devaluation of 345 percent against the SDR on September 26, 1986, Zaire floated 1ts currency, adopting dual official rates during the transition. The fixed-rate market was restricted to the official operations of the Bank of zalre, while the free rate covered the rest of the banking system. The free rate was set initially at the prevalling relance miniere rate, a special rate created to deter diamond smuggling and equalling the black market rate. Subsequently, during the first piase which lasted till 
October 14, 1983, the free rate was set by commercial banks in consultation with the Bank of zaire based on rates they intended to apply to transactions on the free market. The offictal rate was constrained to lie within a spread of 10 percent of the free rate. There, were, consequently, three rates during the transition: the official rate, the (legal) free rate and the (11legal) black market rate, which persisted owing to the retention of capital controls.

In addition to fulfilling various other conditions, the second phase of the transition had two distinctive features: (a) explicit guidelines were set for determining the free rate at a weekly fixing, with banks free to diverge from this indicative rate both for interbank and other transactions based on market conditions; and (b), the spread between the official and free rates was reduced to 5 percent. The net foreign exchange holdings of commercial banks were restricted by the end of the second phase to increase the availability of foreign exchange in the interbank market. In subsequent phases, the spread was reduced to 2.5 percent and in February, 1984, the two rates were unified. 
Table 2: 2AIRE-BLACK MARKET PREMIUM, DERICITS AND INELATION 1980-85

\begin{tabular}{|c|c|c|c|c|c|c|}
\hline & 1980 & 1981 & 1982 & 1983 & 1984 & 1985 \\
\hline Premium & & $\cdot$ & & & & \\
\hline $\begin{array}{l}\text { Perlod average } \\
\text { end-of-period }\end{array}$ & $\begin{array}{l}2.30 \\
2.31\end{array}$ & $\begin{array}{l}2.38 \\
2.47\end{array}$ & $\begin{array}{l}2.34 \\
2.96\end{array}$ & $\begin{array}{l}2.17 \\
1.16\end{array}$ & $\begin{array}{l}1.00 \\
1.03\end{array}$ & $\begin{array}{l}1.00 \\
1.06\end{array}$ \\
\hline Fiscal Deficit/GDP (z) & 0.60 & 3.60 & 7.10 & 2.10 & 2.40 & n.a. \\
\hline Terms of Trade Index & 100.00 & 89.10 & 80.00 & 78.90 & 89.70 & n.a. \\
\hline Base Money Growth $(x)$ & 106.91 & 56.61 & 87.95 & 50.09 & 65.24 & 30.16 \\
\hline Inflation-CPI $(z)$ & 42.07 & 34.91 & 36.23 & 77.13 & 52.23 & 23.82 \\
\hline $\begin{array}{c}\text { Depreciation }(x) \\
\text { Official } \\
\text { Black Market }\end{array}$ & $\begin{array}{l}62.00 \\
25.00\end{array}$ & $\begin{array}{l}56.60 \\
62.10\end{array}$ & $\begin{array}{l}31.20 \\
29.10\end{array}$ & $\begin{array}{l}124.20 \\
107.30\end{array}$ & $\begin{array}{r}180.30 \\
29.40\end{array}$ & $\begin{array}{l}38.00 \\
40.70\end{array}$ \\
\hline
\end{tabular}

Sources and Notes: Black market exchange rates are from the World Currency Yearbook. Official rates, inflation and base money (11nes $14+22 a-26 d)$ are from IFS, IMF. All other data are staff estimates based on officlal data. Depreciation 18 defined as percentage changes in period averages.

As a supporting measure, there was an exchange and trade oystem liberalization timed to colncide with the transition to the unifled iloat. It included the following: the requirement that commercial banks give to the Bank of Zaire 30 percent of the export earnings surrendered to them was dispensed with to increase the volume in the free market; resident foreign currency accounts, used in the past to finance black market activities, were abolished. 15/ Export retention quotas, with a few exceptions, were slso eliminated; guldelines on how commercial banks should allocate their foreign exchange were simplified greatly, with only the broad restriction that 25 percent be allocated for invisibles, and the remaining 75 percent for trade; and the system of Imports financed from the black market, as well as the relance miniere rate, was discontinued. 
The smoothness of the transition may be attributed to two main factors: first, the transactions were well-segmented, with all private sector comercial activity taking place at the free rate. Not only would this have minimized allocative inefficlency, but by avolding exceptlons, it removed the basis for lobbying to have a given company's activity classifled on the fixed, rather than the more depreclated free, tier. Second, the fixed rate was merged with the free rate through a series of discrete adjustments rather than an accelerated crawl, which analytical models would recommend as a desirable course in view of zaire's history of high inflation. In addition, fiscal discipline was tightened in both 1983 and 1984 (see Table 2), which undoubtedly alded the switch in the exchange rate regime by minimizing inflation, and hence, currency depreciation.

\section{Sierra Leone $16 /$}

Sierra Leone floated Its currency, the leone, overnight in June, 1986. The value of was between 3 and 4 just before the float, implying a substantial tax on exports of between 67 and 75 percent. Inflation rose from an annual average of 70 percent for the three years before the float to an annual rate of about 200 percent post-float.

Sierra Leone's experience indicates that in achieving unification, flical reform has to precede changes in the exchange rate regime if awitch from a dual to floating regime is planned with a high initial premium. The reason 18 that in the absence of matching and credible fiscal reform, a politicaliy untenable rate of inflation might emerge. This could result in the perpetuation of sensitive subsidies, such as those on staple foods (rice) and petroleun, which were partly financed by the premium (tax on exports) in the dual regime. Thus, subsidies which were Implicit in the 
dual regime become explicit post.unification, actually worsening the real deficit. In arguing that subsidies be retained, lobbies have only to point at the surge in inflation. Such a scenario actually unfolded in Sierra Leone: privatizing was available as a way of eliminating subsidies prior to the float. However, private traders, who were willing to take over importing and distributing rice before the float, refused to touch it once inflation rose for fear of being blamed for price hikes.

A review of budgetary developments reveals that fiscal discipline was at its weakest when the currency was floated in June, 1986. After falling to a low of 7 percent of GDP in 1983/84, the fiscal deficit peaked at 14 percent in $1985 / 86$. Three main reasons underlay this deterioration in fiscal performance.

First, there was a monotonic decline in the share of tax revenue in GDP, which fell from 16.5 percent in $1978 / 79$ to 5.6 percent in $1985 / 86$.

Second, the subsidies on rice and petroleum, whlch have persisted post-float, constitute a big drain on resources. The rice subsily is distributed via the Produce Marketing Board (SLPMB), which effectively taxes coffee and cocoa to subsidize rice, which it imports, thereby eroding incentives to produce rice domestically as well. The petroleum subsidy accounted for roughly half the difference between the actual deficit of 14.5 percent of GDP In $1985 / 86$ and its budgeted level of 3 percent.

Third, there is no revenue contribution by Sierra Fishing, and suitable tax and royalty contracts with the mining companies do not exist. This is surprising for a country with as rich and diversified a mineral base as Sierra Leone's.

Table 3 summarizes the budgetary situation and exchange rate movements since the inception of the float (comparative pre-float data are not available). The deficit, expressed in US\$ at the black market rate, 
peaked in October 1986 at $\$ 5.4$ million, fell in November and December and then rose again in January 1987. The black market rate, Iike the official rate, depreciated rapidiy. Owing to artificial fixing of the official rate-there was not even one transaction in the interbank market between June, 1986 and March, 1987--it remained at a discount relative to the black market. For practical purposes, the black market is the unified rate for all transactions, with the market made by some 15 diamond exporters.

Table 3: SIERRA LEONE-FISCAL DEFICITS MONETARY BASE AND INFLATION

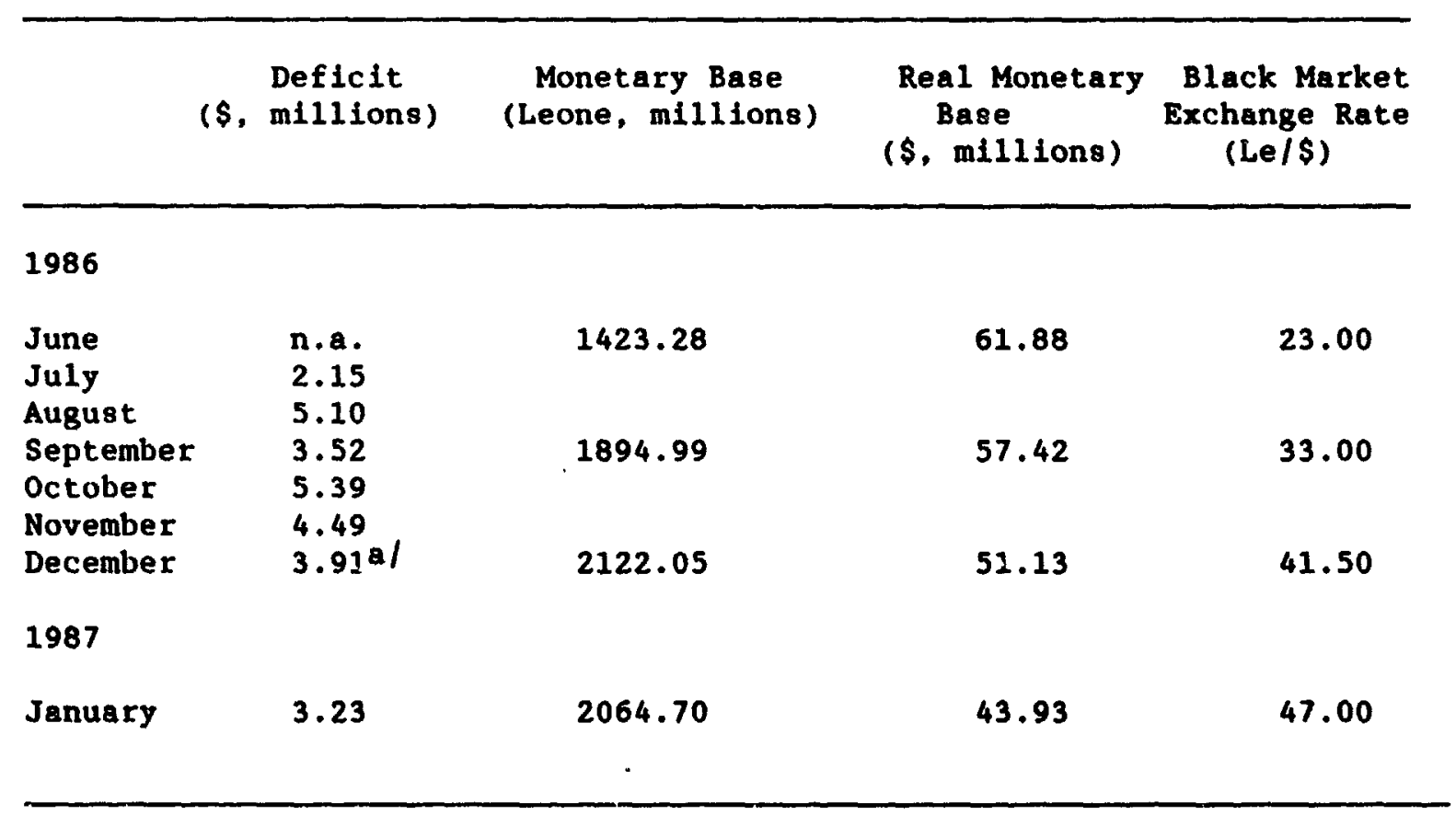

a) Excludes a cash grant from Saudi SAMA of $\$ 5$ million.

Sources and Notes: Bank of Sierra Leone (B.S.L.) except black market rates, which are staff estimates. Conversion to U.S. dollars is at black market rate. Monetary Base is defined as currency outside banks + comercial banks's deposits with B.S.L. + cash-in-hand of commercial banks + net claims on government by commercial banks.

The rapld depreciation of the Slerra Leonean leone shown in Table 3 has been fuelled by the fiscal deficit. It has been financed by the Inflation tax - printing money and, compared to prevaliing rates of 
Inflation, low nominal intereat-bearing treasury b1118, $17 /$ Fron Table 3 , the average monthly real deficit between August, 1986 and January, 1987 was about US $\$ 4.5$ million. The real monetary base was roughly $\$ 50$ million, implying that an inflation rate of 9 percent per month was required to generate the necessary selgnorage for the deficit. For the six months ended December, 1986, this Implies 70 percent inflation, which corresponds closely to actual inflation, and hence, the depreciation of the leone.

The real monetary base declined monotonically between June, 1986 and January, 1987. High inflation has created a disincentive for holding leone assets and provided a motive for diversifying into dollars to avold the Inflation tax. The shift to bank accounts abroad, or even to dollar b1118, has reduced the real monetary base 80 that a higher rate of inflation - the tax rate - is required to generate the same real revenue. The decline 1r. the ratio of quasi-money (time and savings deposits) to M1 (currency outside banks plus demand deposits) from 0.35 in 1985 to 0.31 in June, 1986 and 0.23 in December, 1986, conflrms this.

There is little doubt, given the substantial initial level of the premiun and low policy credibility, that the Slerra Leonean float was poorly timed. While switching to a float may have complicated the fiscal reform process, it has highlighted the urgency of the needed reforms.

\section{$\underline{\text { Zambia }}$}

Zambla's experience Indicates that exchange rate reform without fiscal reform may be futile. The tradeoff is between two sets of circumstances, both unpalatable. Not introducing exchange rate reform and living with a dual regime is costly in terms of misallocation and policy credibility. On the other hand, unifying at a market-determined rate 
without fiscal reform could produce high inflation and rapid currency depreciation, which have welfare costs and impede subsequent fiscal reform, as the Slerra Leonean case study showed.

Over the years, Zambia has experimented with a variety of exchange rate regimes. In December, 1971, it delinked 1ts currency, the kwacha, from the pound sterling to establish a peg to the U.S. dollar. This was followed In 1976 by a move to "controlled float" and an adjustable peg to the SDR. In July, 1983, the link to the SDR was abandoned in favor of a crawling peg: the kwacha was linked to a currency basket and depreciated every month at a predetermined rate. Rationing through import licensing, however, was retained. The depreciation was substantial between 1983 and 1985 (8ee Table 4 below). This exchange rate rule was replaced by foreign exchange auction in October, 1985. Interest rates were decontrolled a month earlier to mobilize savings, promote a more efficient use of financial resources and ensure compatibility with the new, market exchange rate regime.

Three basic motives underlay the decision to start an auctions first, to adjust to terms of trade shocks which had inftially been thought transitory and responded to by running down reserves and borrowing; second, to cope with external balance problems; and third, to minimize administrative allocation by moving to a market-clearing exchange rate. There was some recognition that the exchange rate rule in vogue between 1983 and 1985 was not resulting in either an "equilibrium" or unifled exchange rate (see Kaunga (1985) and Pinto and van Wijnbergen (1987)). The data in Table 4 below confirm this. The terms of trade declined steadily and the black market premium persisted despite an increase in the official rate of devaluation after 1983 . The flscal deficit/GDP ratio was also consistently high, despite temporary reductions in 1983 and 1984. 


\section{Assessment of the Zambian Experlence}

The adoption of market-determined exchange rates 18 motivated by two broad considerations: an exchange rate adjustment is needed, but the magnitude of change cannot be easily determined; and the reliance on rules does not produce a desired outcome, e.g., unification. Once the decision is made to let market forces determine the exchange rate, the choice is between an auction and an interbank float.

The main differences between the two mechanlsms are the following: 18 / (a) commercial banks have a larger role in interbank floats, since they hold foreign exchange and re-sell it to private sector importers after buying it from the central bank. They therefore have some incentive to ensure it is "fairly" priced. In auctions, the main administrative burden Is on the central bank, to which all foreign exchange is surrendered. Further, there is no re-sale. The commercial banks merely intermediate the transaction; (b) in floats, the exchange rate in principle changes continuously in response to news and market conditions, unlike in an auction, where it is fixed in the inter-auction period.

In practice, both mechanisms have been equally open to manipulation by the authorities. The interbank floats in Sierra Leone, and to some extent, In Nigeria, provide evidence that the exchange rate can be manipulated either through systems design or unannounced intervention. Similarly, auctions are also manipulable, by the authorities or exporters and importers, if the foreign exchange market is oligopolistic.

In Zambia, the manipulation of the auction has been mainly by the authorities. First, entry restrictions were introduced, including proof of advance payment of various taxes and restrictions on borrowing to 
participate in the auction. As a result, several bids were disqualified in some auctions, artificially appreclating the exchange rate. Second, the auction switched from a cash to a comitment basis, Implying that funds in excess of what could be sustained were being auctioned off. Neither of these interventions stabilized the exchange rate, or stemed its depreclation, for long. Even the switch from a marginal to a Dutch pricing mechanism, which was motivated by the idea that the marginal auction had a "depreciation" bias, did not alter the path of the exchange rate. $19 /$ The most significant development following the auction has been a big jump in the fiscal deficit/GDP ratio and hence, the dependence on the inflation tax, as Table 4 attests. The rise in the fiscal deficit/GDP ratio following the auction 18 remarkable. Moreover, this is not due to a tax collection problem. To the contrary, Zambia has one of the highest tax revenue/GDP ratios in sub-Saharan Africa (Shalizi, Gandhi and Ehdaie (1985)). The expenditure/GDP ratio virtually doubled in 1986 relative to 1985.

While a detalled analysis of this phenomenon 18 pursued elsewhere (Panayotacos (1987)), the lesson that emerges is clear: exchange rate reform without fiscal reform will not work. Moreover, switching to a float could exacerbate an already difficult budgetary situation. 
Table 4: 2AMBIA-BLACK MARKET PREMIUM, DEFICITS AND INFLATION $1980-1986$

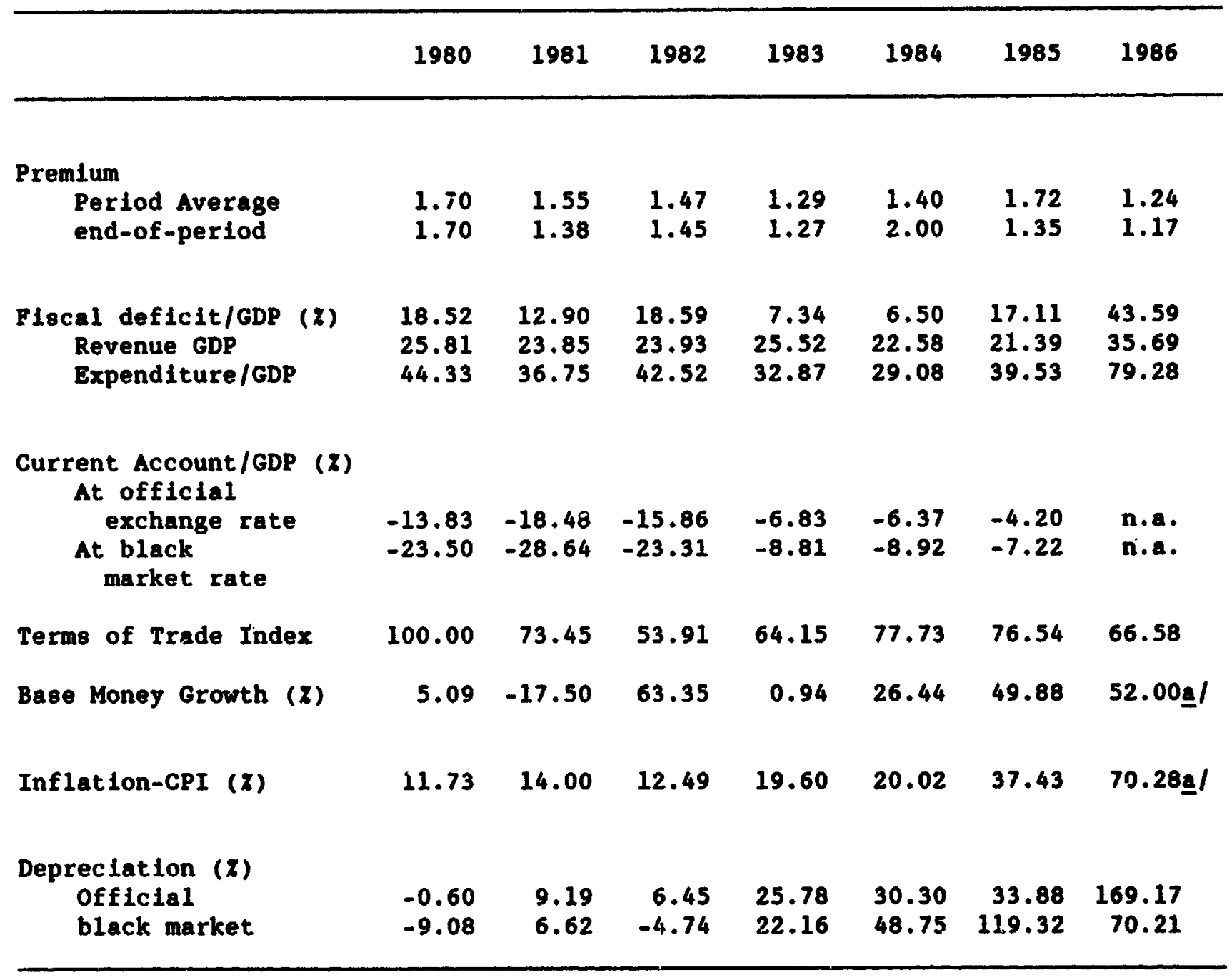

Sources and Notes: Black market exchange rates are from the World Currency Yearbook. Official rates, Inflation, fiscal data and base money (IInes 14+22a-26d) are from IFS. Flscal data for $1985-86$ and terms of trade are staff estimates based on official data. Depreciation is defined as percentage changes in period averages.

al estimate. 
IV. CONCLUDING REMARKS

\section{Policy Conditionality: The Budget and Exchange Rate Arrangements}

Paradoxically, the first step in exchange rate reform for "high $\phi$ " countries may have to be a fiscal one: recasting the budget to $f i x$ the size of the implicit tax revenues from exports via the premium. The tax-subsidy redistribution within the private sector as a result of foreign exchange rationing is also important. This involves identifying the potential gainers (e.g., agriculture) and losers (e.g., commerce, protected manufacturing using imported inputs) in the event of unification. Such identification will make plain the political presoure points likely to emerge upon unification.

Four distinct 18sues arise: (1) Can government spending be justifiably reduced? (2) Is there an equitable distribution of the tax burden based on Ramsey-type considerations? (3) Are existing tax instruments apart from the premium and rate of inflation being used to the hilt, or are the latter being used as the easy way out? $20 /$ And (4), if the export tax is being used in lieu of a land tax, or profits tax, which are more difficult to collect, is the optimal export tax zero, as implied by unification? $21 /$ In confunction with the preceding analysis, these 1deas suggest a changed emphasis in loan conditionality. Where unification is an issue, conditionality and technical assistance with respect to the budget might be more appropriate than conditionality directly related to exchange rate arrangements, suggesting a stronger role for public expenditure reviews and tax reform. The length of the loan is also important, since fiscal reform takes time: improving information flows, perhaps negotiating new contracts with MNCs in the mineral sector, gradual elimination of subsidies, review 
and restructuring of public investments and expenditure, etc. A short-term loan focused purely on exchange rate unffication, e.g., adopting an auction or interbank float, worsens the problem of post-unification inflation: the government must not only replace the lost revenue from exports, but also repay the loan on short order.

\section{Summing Up: Some Guidelines for the Transition}

The black market premium on foreign exchange 18 interpreted as a tax on exports, thereby setting up a trade-off between the premium and the rate of inflation in financing fiscal deficits. In order to depreciate the real exchange rate and stimulate exports, the premium must be reduced. Further, for a given real deficit and plausible initial conditions, inflation will rise upon unification of officlal and black market exchange rates: the 1088 in revenues from the premium is replaced by a higher tax on money •

The analytical ideas are illustrated with recent country experience in Sub-Saharan Africa. The results apply when the premium is large--much larger than explicable by capital controls alone--80 that the revenue and redistributive imflications are significant. Typically, trade transactions are strictly rationed via import licenses, so that at the margin, the black market rate applies to both capital and trade transactions. The asset demand for forelgn exchange is satisfled via the black market.

The real deficit can rise upon unification for two reasons: first, the higher inflation that results make it difficult to maintain real tax revenues (Tanzi (1977)); second, rent seekers may lobby successfully to get the implicit subsidies they were receiving through import licenses at the official exchange rate under the erstwhile regime converted into explicit subsidies. 
The main policy conclusion is that if policy credibility is low and Initial level of the premium high, with significant revenue and redistributive implications, the pace of reform should be set by the feasible speed of fiscal reform. Accelerating rates of depreciation above prevalling inflation in the absence of credible flscal reform could raise the black market premium as a result of pre-emptive portfolio shifts into dollars, thereby jeopardizing the survival of both flocal and exchange rate reform. Moreover, such policy will not achleve real depreciation uniess the premiun falls. Likewise, overnight adoption of floats is likely to meet with considerable political and social opposition as inflation rises, creating the possibility of policy reversals as evidenced by recent events in Slerra Leone, Somalia and zambia. The "best" route, consequently, might be to gradually relax rationing, accompanying this with discrete devaluations, with the pace of reform being set by the speed of fiscal reform.

Some additional guidelines might be helpful. First, commercial transactions can be transferred to the black market. Such legitimization of the black market could be an important step in eventual unification and the removal of rationing. If the goal is to ultimately have a floating interbank market, commercial banks could be permitted to buy foreign exchange from the black market and resell it to importers at a market rate. Second, in many instances, foreign currency denominated accounts are created in the domestic banking system to encourage capital reflows, i.e., the return of money invested by private citizens abrood. The nature of these accounts is important. For example, are these going to be checking, or savirags accounts? Are withdrawals going to be made in local, or forelgn currency? Could such accounts compete with local currency checking accounts for holding transactions balances? 
Permitting imports through the black market provides a channel for repatrlating dollars held abroad. Forelgn currency denominated accounts do not augment officlal reserves. They merely make it easier and cheaper to hold foreign financial, rather than domestic financial, assets. By Increasing substitutablifty between domestic and foreign assets, such accounts lower the base for the inflation tax, calling for a higher rate of inflation for a given real fiscal deficit. Introducing ouch accounts therefore needs to be carefully considered.

Third, should dual offlctal rates - as distinct from the black market rate - be adopted in the transition? In particular, a two-tier 8ystem with a fixed (and more appreclated) first-tier rate, and a floating narket-determined second-tier rate? If adopted, the dual system should be designed in a way that incentives for new economic ventures and investments are governed solely by the floating, market-determined rate. This can be done by letting the floating rate apply to all commercial transactions, including those of state-owned enterprises and restricting the fixed rate to purely government transactions and foreign interest payments on existing, but not new, devt.

Fourth, the transition provides an opportunity to design and implement mechanisms that will speed up information flows in the domestic banking system and the varlous minlotries: Th1s will ensure that Information on key macroeconomic variables such as government opending, domestic credit to the government and private sector, money growth rates and price data are avallable punctually. Such data are basic inputs that must be avallable in timely fashion to market participants, in addition to other data, such as terms of trade movements. 
Most importantiy, flocal reform needs to be designed and Implemented in a credible and sustainable manner, with a clear assessment of the taxes and subsidies implicit in the dual exchange rate regime.

Lastly, It would be incorrect to conclude from this study that a developing country should never float its currency. This decision should depend upon the credibility of accompanying fiscal reform and the initial 81ze of the premium. Even a country that follows the Ghanaian route described above will, at some stage, need to float its currency to achleve unification. At a minimum, the rationing of commercial transactions has to be eventually eliminated. It is difficult to think of doing this on a sustained basis with fixed exchange rates. Once unification with or without capital controls is attalned, however, there remains the decision of whether to continue with a float as a permanent mechanism. The empirical experience of developing countries over the next few years should give some insights into this issue; but this issue should not be separated from the inflation tax and the credible sustainability of fiscal reform. 


\section{FOOTNOTES}

1. Subject to the provision that the float on the trade account is free of official manipulation.

2. These results are developed heurlstically here. A rigorous analytical treatment may be found in Pinto $(1987 \mathrm{~b})$.

3. Not only is this assumption realistic, but it is analytically justifiable given rationing, and enables a consistent comparison of the dual and unified regimes, as we shall see later.

4. The approach here follows Kharas and Pinto (1987).

5. This and the next two sections are based on Pinto (1986, 1987b). Some of the basic model features come from Lizondo (1984, 1987).

6. In addition, there is a spending function linking I to wealth. See Pinto (1987b).

7. Suppose the curve BB was completely above the horizontal 1ine, $\phi=1$. Then financing the deficit entirely through the inflation tax would not be feasible and unification $(\phi=1,1, e, b=e)$ would create serious stability problems (see, for example, Kiguel (1987)).

8. Notice that $\pi_{h}\left(g_{0}\right)>\pi_{h}\left(g_{1}\right)$. This is because to the right of $A, \eta>1$ so that a lower rate of inflation is required to generate the higher seignorage corresponding to $g_{1}>g_{0}$. Further, of the dual equilibria upon unification, the low inflation equilibrium is saddle-point stable and the high inflation equilibrium completely locally stable under rational expectations (see Pinto (1987b)).

9. This section summarizes chapter II of Pinto (1987a). In particular, much of the important and interesting institutional detail may be found there.

10. Formulating exchange rate adjustments based on the difference between the actual and some postulated equilibrium level of the official real exchange, defined as the exchange rate adjusted for forelgn relative to domestic prices, was common in 1983. This approach included the idea that for high inflation countries, the rate of crawl be allowed to exceed prevalling inflation (see Johnson et al., (1985)). Edwards (1985) emphasizes that the equilibrium exchange rate changes over time and is endogenous, depending upon fiscal, monetary, external debt and trade policy. Deciding what this level is based on a historical time serles is more art than science.

11. A discussion of Nigerian economic policy during and soon after the oil boom may be found in Pinto (1987c).

12. An excellent account of the oil boom and its aftermath is contained in "Structural Adjustment Programme, July 1986 - June 1988", a Nigerian government document presented to the Loncisn Club in June, 1986. This 
Insightful paper discusses key corrective measures in the areas of trade and exchange rate policy, public investment, agriculture and externai debt.

13. Given the low level of inflation, and hence of the inflation elasticity of the demand for nairas, plus the government's being a net seller of dollars, It is likely, that both responses arrested the growth of the premium as it rose in response to the collapse of oil prices (sharp decline in $\mathrm{p}_{x^{--s e e}}$ section II).

14. Paras. 38 and 39 of the "Structural Adjustment Programe, July 1986 June $1988^{\prime \prime}$, provide the rationale for moving to a market exchange rate, based on eliminating the economic costs of the import licensing system.

15. One possible motive is to increase the flow in the free market. The other more important one is to avold increasing the degree of substitutability between domestic and forelgn financial assets, which would reduce the base for the inflation tax.

16. Sierra Leone experimented briefly with an auction in 1982 (Krumm (1986) contains details) before reverting to a fixed peg to the U.S. dollar until the float in June, 1986.

17. By issuing non-interest, or relative to inflation, low nominal interest bearing debt such as currency and treasury bills, the government inflicts a capital loss on the holders of its outstanding stock of liabilities, thereby making a revenue gain. It is necessary to make a case-by-case determination of the components of base money, which traditionally includes only the liabilities of the central bank, namely, currency outside banks and commercial bank reserves.

18. This description reflects the prevailing institutional differences between the two mechanisms as actually implemented in various countries.

19. For details, see Panayotacos (1987). If it is believed that the bidding strategies of participants depend upon the pricing mechanism, one possibility is to randomize over the marginal and Dutch pricing rules after the bids are in. However, Zambia's experience lindicates that consistency between fiscal and exchange rate policy is at least as important as the auction design itself.

20. See Aizenman (1986) for a welfare analysis of a related problem.

21. Suppose $\phi=3$ to start with, implying a tax rate of 67 percent, and that the export is bought by a commodity board which sets domestic prices with reference to the official exchange rate. Upon unification, the government might find it difficult to justify an explicit tax of 67 percent. It may however, decide upon a lower tax of say, 15 percent. This has the advantage of eliminating the misallocation costs associated with cheap imports in the erstwhile dual regime, since importers must now pay the unified rate. 


\section{Appendix $1^{1}$}

\section{Proof that the Production Possibility Front ler (PPF) is Cuncave}

The key to understanding this proof to the recognition that there are essentially two goods: the home good (H) and the export good $(X)$. In stage one, the production levels of $H$ and $X$ are chosen using the PPF and relative price line. In stage two, total exports, $x$, are distributed between the official and black markets by equating marginal returns in the two markets. Technology $H=L^{a} I^{1-a}, \quad a \in[0,1)$, where $L$ Is labor and $I$, Imported Inputs.

$X=E-L$, where $[$ is the given endowment of labor.

Steady State The balance of payments equation (eq. (4)) 1s:

$$
P_{X} X=I+g+\dot{F} \text {, where }
$$

8 is govermment imports ( $\$, \mathrm{P}_{x}$ is the $\$$-price of exports and $\dot{F}$ is private sector dollar accumulation. In steady-state, therefore, $I=P_{x} X-B$.

Substituting into $H=\mathrm{L}^{a} \mathrm{I}^{1-a}$ gives the steady-8tate technological relationship between $H$ and $X_{2}$

$$
H=(E-x)^{a}\left(p_{x} x-g\right)^{1-a}
$$

Stralghtforward differentlation can be used to show that $H_{x x}<0$, 80 that $\mathrm{H}$ is a otrictly concave function of $X$. Purther, $H=0$ when $X=g / p_{x}$ or when $X=E$. We require that $p_{x}[>g, 1 . e$. , that the maximum feasible supply of dollars exceed the government's requirements. The PPF 18 shown graphically in Fig. 1 in the text.

At $X=X *=\left((1-a) E+a\left(g / p_{x}\right)\right), H_{x}=0$.

I/ Further technical details are avallable in PInto (1987b). 
$-43$

Since domestic residents consume only home goods, it follows that the optimal point to produce at $18 \mathrm{X*}$, where $\mathrm{H}$ is maximized. The solution to the optimization problem (eq. (1) In PInto (1987b)) gives $x^{\text {opt }}=\left[-L_{1}=\right.$ $\left[(1-a)\left[+a \phi\left(g / p_{x}\right)\right] /(1-a+a \beta)\right.$, where $\phi \equiv(b / e)$ is the black market premium. Clearly, $x^{\circ p t}<X^{*}$ with $x^{\circ p t}=X^{*}$ when $\phi=1$, 1.e., the exports tax via the premium is removed. In fact, $H_{X}\left(X=x^{O p t}\right)=b p_{X}(1-1 / \phi) / p_{H}$, which 18 zero when $\phi=1$. So long as $P>1, X^{\circ p t}<X^{*}$ and consumption of home goods 18 less than Its maximum feasible level corresponding to $x^{*}$. Not only does this capture the production distortion as the result of the tax on exports via $\phi$, it also captures the notion of import compression and its effect on lower GDP growth as a result of stunted exports. 


\section{REFERENCES}

Aizenman, Joshua, 1986. "On the Complementarity of Commercial Policy, Capital Controls and Inflation Tax", Canadian Journal of Economic8, XIX, 1, pp. 114-133.

Calvo, Guillermo A., and Carlos Alfredo Rodriguez, 1977. "A Model of Exchange Rate Determination under Currency Substitution and Rational Expectations", Journal of Political Economy 85, pp : 617-625.

Dornbusch, Rudiger, 1986, "Special Exchange Rates for Capital Account Transactions, "World Bank Economic Review, 1, 1, pp. 3-33.

D.V. Dantas, C. Pechman, R. Rocha and D. Simoes, 1983. "The Black Market for Dollars in Brazil", Quarterly Journal of Economics 98,1 , pp. 25-40.

Edwards, Sebastian, 1985, "Real Exchange Rate Misalignment in Developing Countries: Analytical Issues and Empirical Evidence". CPD Discussion Paper 1985-43, The World Bank.

, and Sweder van Wijnbergen, 1983. "The Welfare Effects of Trade and Capital Market Liberalization: Consequences of Different Sequencing Scenerios", NBER Working Paper No. 1245, Cambridge Mas 8..

Johnson, G.G., et al, 1985, "Formulation of Exchange Rate Policies in Adjustment Programs", Occasional Paper 36, IMF.

Kaunga, E.C., 1985. "Auctioning of Forelgn Exchange and How It W11l Affect Industry", Paper presented at a Seminar on the Economic Problems Facing the Zambian Economy, University of Zambia.

Kharas, Homi and Brian Pinto, 1986, "Exchange Rate Rules, Black Market Premia and Fiscal Deficits: The Bolivian Hyperinflation", mimeo. The World Bank.

Kiguel, Miguel A., 1987. "Stability, Budget Deficits and the Monetary Dynamics of Hyperinflation", mimeo, The World Bank.

Krueger, Anne 0., 1974. "The Political Economy of the Rent-Seeking Society" American Economic Review 64, pp. 291-303.

Krumn, Kathie L., 1986, "Recent Experiences with Exchange Rate Auctions", CPD Discussion Paper 1986-29, The World Bank. 
Lizondo, Jose Saul, 1984, "Exchange Rate Differential and Balance of Payments under Dual Exchange Markets". Journal of Development Economics, forthcoming.

- 1987. "Unification of Dual Exchange Markets", Journal of International Economics 22; pp. 57-77.

Panayotacos, Paul, 1987, "Transition Issues in Exchange Rate Unification: The Case of Zambia", mimeo.

Pinto, Brian, 1986, "Fiscal Deficits, Inflation and Parallel Exchange Markets in Ghana: Monetarism in the Tropics?", CPD, The World Bank.

, 1987a. "Exchange Rate Unification and Budgetary Policy In Sub-Saharan Africa", mimeo., The World Bank.

- 1987b. "Black Markets for Foreign Exchange, Real Exchange Rates and Inflation: Overnight v8. Gradual Reform in Sub-Saharan Africa", mimeo., The World Bank.

, 1987c. "Nigeria During and After the 011 Boom: A Follcy Comparison with Indonesia", World Bank Economic Review, 1, 3, pp. 419-445.

and Sweder van Wijnbergen, 1987, "Exchange Rate Regimes in Africa", mimeo., The World Bank.

Quirk, Peter J. et al., 1967. "Floating Exchange Rates in Developing Countries", Occasional Paper 53, IMF.

Sachs, Jeffrey, 1987. "The Bolivian Hypertnflation and Stabilization", American Economic Review Papers and Proceedings, 77, 2, pp. 279-283.

Shalizi, zmarak, V. Gandhi and J. Ehdaie, 1985, "Patterns of Taxation in Sub-Saharan Africa", CPD Discussion Paper 1985-48, The World Bank.

Tanzi, Vito, 1977. "Inflation, Lags in Collection and the Real Value of Tax Revenues", IMF Staff Papers, March. 
Titie

WPS15 Stimulating Agricultural Growth and Rural Development in Sub-Saharan Africa

WPS16 Antidumping Laws and Developing Countries

WPS17 Economic Development and the Debt Crisis

WPS18 China's Vocational and Technical Training

Harold Noah John Middleton

June 1988

W. Ketema 33651

Christiaan Grootaert June 1988 Technical Education

WPS20 Imports and Growth in Africa

WPS21 Effects of European VERs on Japanese Autos

Jaime de Melo

Patrick Messerlin

June 1988

Jean-Paul Azam

June 1988

Patrick Guillaumont Syiviane Guillaumont

Contact

H. Vallanasco 37591

S. Torrijos 33709

C. Papik 33792

Ramon Lopez

June 1988 34678

61679

WPS22 Methodological Problems in CrossCountry Analyses of Economic Growth

WPS23 Cost-Effective Integration of Immunization and Basic Health Services in Developing Countries: The Problem of Joint Costs

A. Mead Over, Jr.

July 1988

N. Jose 33688

WPS24 World Bank Investments in Vocational Education and Training

John Middleton

July 1988

W. Ketema Terri Demsky 33651

WPS25 A Comparison of Alternative Training Modes for Youth in Israel: Results from Longitudinal Data
Adrian Ziderman
July 1988

w. Ketema 33651 
TIt10

WPS26

Changing Patterns in Vocational

Education

WPS27 Family Background and Student

Achievement

WPS28 Temporary Windfalls and Compensation

Arrangements

Bela Balassa

Marlaine E. Lockheed

Bruce Fuller

Ronald Nyirongo

July 1988

July 1988

W. Ketena

33651

R. Rinaldi

33278

June 1988

N. Campbell

33769

WPS29 The Rolative Effectiveness of single-Sex and Coeducational Schools

in Thalland

Emmanuel Jimenez

Marlaine E. Lockheed

WPS30 The Adding Up Problem

Bela Belasso

WPS31 Public Finance and Economic Development Bela Balassa

wPS32 Munlcipal Development Funds and

Internediaries

Kenneth Davey

July 1988

R. Blade-Chares

33754

John Cuddington

Lance Taylor

WPS35 Improving the Allocation and Management of Public Spending: Some

Lessons of African Experience

Stephen Lister

WPS36 Means and Implications of Soclat

Security Finance in Developing

Countries

Douglas J. Puffert

WPS37 Black Market Premia, Exchange Rate

Unification and Inflation in

Sub-Saharan Africa

Brian Pinto

July 1988

R. Bl ade-Chares 33754 